\title{
An Interdisciplinary Study of Narrative Structure in Dash $A k o l$ as a Short Story and Dash Akol as a Movie
}

\author{
Dashti, Azam ${ }^{1^{*}}$ \& Hadidi, Yaser ${ }^{2}$ \\ ${ }^{1}$ Shahid Behesti University, Tehran, Iran. \\ ${ }^{2}$ The University of Tabriz, Tabriz, IRAN \\ * Corresponding author; Email: azam_dashti@yahoo.com
}

\begin{abstract}
This paper undertakes an interdisciplinary study of the short story "Dash Akol" and the movie adapted from it. "Dash Akol" is a short story written by a famous Iranian author Sadeq Hedayat in 1932. Hedayat's "Dash Akol" was made into a movie in 1971 by Masoud Kimiai. There are some discrepancies between the short story "Dash Akol" and the movie, triggering a number of significant implications. This article discusses these discrepancies along with Hedayat's and Kimiai's narrative techniques. To this end, it applies Genett's (1988) Narrative Discourse and his three main narrative methods: narrating, characterization, and focalization. Meanwhile, it brings in Rimmon-Kenen's (2002) strategy to study characters, and Stam and Burgoyne and Flitterman-lewis (2005) to show the ways in which the movie has deviated from the story. In terms of characterization, it studies traits such as, action, speech, naming and setting.
\end{abstract}

Keywords: Adaptation; characterization; Dash Akol; focalization; Hedayat; Kimiai; narrative technique.

\section{INTRODUCTION}

The relationship between literature and film has been the subject of numerous reflections and analyses. Most critics see art, literature and film in terms of a living mosaic, a dynamic intersection of textual surfaces (Sanders, 2006, p. 3).The very quality can be seen in a quite successful adaptation of the short story of "Dash Akol" into a movie. There are debates around Dash Akol's success as a film and the degree to which it remains faithful to the source text. Apart from all these controversies surrounding the dialectic between the two genres, one obviously based upon the other and borne from it, it goes without saying that the movie has brought the short story into the limelight, successfully targeting and winning over the attention of a wider audience.

"Dash Akol" is one of the ten stories of Sadeq Hedayat's book Se qatreye khun (Three Drops of Blood, Tehran, 1932). In the opening lines, the narrator informs the reader that Kaka Rostam is Dash Akol's rival who seeks to defeat and, quite possibly, humiliate, him. The story opens in a teahouse, where Kaka Rostam is challenging and provoking Dash Akolinto anew brawl. All of a sudden, a man enters and informs Dash Akol that Haji Samad, his old friend and an affluent merchant had died and chosen
Dash Akol as an executer to his estate. Dash Akol makes his way down to the Haji's house to convey his condolences and talk to the widow. While there, Dash Akol catches sight of Marjan, Haji Samad's daughter Marjan. Having come to see the "town's hero and their protector" (Hedayat, 1995, para.15), Marjan looks at him from behind a curtain. Momentarily, Dash Akol finds his eyes fastened upon hers, eyes that take him by storm. In any event, her stunning eyes had worked their magic and had turned Dash Akol's life upside down. His face flushing crimson, he dropped his head" (Hedayet, 1995, para.15). Believing that he is too old to marry her, he suppresses his love for her. However, when drunk and lonely at home, he would confess his love for Marjan to his parrot: "Marjan, your love is killing me...". After seven years, a suitor "uglier and older than himself' (Hedayat, 1995, para.27) arrives for Marjan. Dash Akol makes arrangements for Marjan's wedding and then with eyes full of tears leaves Haji's house for Mullah Esaac's to drink and get over such searing heap of grief. On his way back, Kaka Rostam comes across him and, through sarcastic and provoking words, poses a challenge. In that wrestling, Kaka Rostam throws a cowardly stab at Dash Akol with Dash Akol's own cutlass, wounding him mortally. Dash Akol dies on the following day. But before his death, he asks Valikhan, Marjan's brother, 
to look after his parrot. The same afternoon while Marjan was looking at the parrot,"suddenly the parrot, in a voice that echoed Dash Akol's, said, "Marjan... Marjan... you've killed me. Whom can I tell? Marjan, your love has killed me." (Hedayat, 1995, para. 40). Marjan's tears roll ceaselessly down.

Kimiai, a famous Iranian director, turned the short story into a black and white movie. The movie sounds quite faithful to the source text, yet to meet the needs of the time and cinematic audience, some differences were inevitable. In fact, Kimia reproduces Hedayat's short story of Iran in the 1920s into the Iranian context of the1970s; the short story paints luti and trickster (ayyar) custom while the movie depicts a hybrid tough-guy genre; Kimiai's Dash Akol retains a dual type of Iranian and western tough-guy image; in fact, "the integration of Iran into the global economy and exchange of relations with the American western image added another dimension to the tough-guy acting repertoire. Directors such as Kimiai adapted the western codes"; Dash Akol is at once Robinhood, a cowboy and a dash mashti, the Iranian sort of toughguy (Naficy, p. 284).

It can be observed that the public is always attracted to Hollywood and western movies replete with erotic and sexual incitements. Kimiai's dependency on private sector support made him liable to public tastes making room for erotic scenes; while in Hedayat's short story the issue is repressed. Iranin the 1920 s had a more repressed and conventional discourse regarding the expression of love and cardinal desires while platonic love was a more decent expression of love. In Iranian literature and culture, a luti is chaste until marriage; Sadeq Hedayat's short story which is an expression of luti customs is faithful to this discourse. However, Kimia has a new narration of these customs. His work is a hybrid creature of Iranian and western codes.

\section{METHOD}

To trace the narrative strategies employed by Sadegh Hedayat and Masoud Kimiai and draw an analogy between these works, we use Genette's three components of narrative strategy: narrating, characterization, and focalization. First, using Genette' narrative strategy, we explore the temporal relation in the narrative text. Then we deal with the narrative level of story. Perceptibility and reliability of narrative are two other parameters to look at in these two works. Through Rimmon-Kenan's strategy, Hedayat and Kimiai's methods in representing the character's speech and thought are discussed. Character existence is an important issue that requires close attention.
To present characters' traits, direct and indirect methods will be applied. In the indirect method, settings, naming, and, above all, characters' speech and actions are discussed. Finally, we revisit Genett's Focalization to discuss the question of "who sees?".

\section{Temporal Position}

Among the four types of narrating, from the perspective of temporal positions, namely "subsequent (the classical position of the past-tense narrative [...]); prior (predictive narrative, generated in the present $[\ldots]$ ); simultaneous (narrative in the present contemporaneous with the action); and interpolated (between the moments of the action)" (Genette, 1988), a great deal of Kimiai's narrative is in the simultaneous form, for the movie is presented in free direct narration, while Hedayat mainly uses past tense.

Hedayat's use of the past style tense of narrating causes the readers to sympathize with the characters in the story. According to Henry Allay (1979), "compassion and pastness go hand-in-hand" (Allay, 1979 , p. 404). In the short story, the gap of time separating the narrator from the world of Dash Akol facilitates the connections between one event and another and creates a cause and effect relationship between the events. Hence, what adds to the depth of Hedayat's tragic story is the strong relation between the events.

\section{Typology of Narrative Level}

Critical factors in analyzing the narrative structure are the narrative level to which the narrator belongs, participation or absence of narrator in the story, the degree and sign of narrator overtones and covertness, and finally reliability or unreliability of narrator. All these factors in analyzing the narrative structure of a text comprise a typology of narrative level (Genett, 1988). Under the phenomenon of the narrator level, there are two basic types of narrators: "intra diegetic" and "extra diegetic" (Genett, 1988). These two can be categorized into hetero diegetic and homo diegetic. The narrator in "Dash Akol" is extra diegetic because it is a narrator who is absent from the story and is a first degree narrator. It is hetero diegetic because it is out of the story, not a character inside the story. In Kimiai's movie, the narrator is extra diegetic-hetero diegetic as well. But it is noteworthy that the cinematic type of narrator manifests itself through a range of cinematic codes such as visual and sonic registers (Stam \& Raengo, 2005, p. 96-7). Music is an important sonic register in the hands of the extra diegetichetero dietic narrator, interweaving the scene and unfolding of the movie. As Sfandiar Monfaredzadeh 
argues, the movie's music composer provides the movie Dash Akol with a sort of jazz music which echoes two Iranian rituals; one pahlevani and zoorkhane ritual, the other one, Persian mourning epic and Tazieh. Pahlevani style is the traditional heroic epic sport music, descending from martial arts; Tazieh is a traditional Persian theatrical genre for mourning, in which drama is conveyed through music and singing. Kimiai makes music into a powerful extra diegetic-hetero dietic narrator. The music steers the Iranian mind towards the tragedy of Saiawush, a famous hero in Shahnameh and, more importantly, Karbala and holy Hossein; the music associates Dash Akol with these Persian tragic heroes and thus foreshadows his tragic death.

In terms of narrative perceptibility, it should be considered that the narrator is never absent in the story. Even when the story is based on a dialogue, there is a narrator who quotes the dialogues. Seymour Chatman proposed six signs of the narrator's presence in the text: Description of setting, identification of characters, temporal summary, definition of characters, reports of characters' actions (1980). Even in a narrative structure, in which the narrator is seemingly covert, signs of overtone can be detected. For instance, in Kimiai's movie, the monologue at the beginning of the movie makes the audience cognizant of the narrator's presence: "Everyone in Shiraz knew that Dash Akol and Kaka Rostam were such bitter enemies...." (Hedayat, 19995, para.1). At this point, the camera assumes the narrative role and pans to one of Dash Akol and Kaka Rostam's encounters and alterations. Hedayat's story starts with the same line, but in the absence of the camera, it keeps its overt mode, with the reader constantly feeling the presence of the narrator.

Narrators are categorized as reliable and unreliable on the basis of their ability to establish and verify the facts of the fictional world. A reliable narrator, in Rimmon-Kenan's (2002) words, is one whose rendering of the story and commentary take on an authoritative quality towards the fictional truth in the eyes of the reader (p.101). In Hedayat's stories, this authority is preserved such that the reader hardly doubts the narrator's words and the characters' actions; however, some scenes in the movie threaten the narrator's authority. Hassan Fiad (2003), the film director, critic, and the professor of UCLE University, questions Kimiai's cliché representation of Dash Akol; he criticizes Kimiai sending Dash Akol many times to Mullah Esaac's house to drink, listen to Motrebs and watch the dancer's flirtatious advances, right after the Haji's funeral, all of which, according to the Iranian tradition, seems odd and twisted. Also he believes, in the last scene, that Dash Akol's ability to strangle Kaka Rostam to death after being fatally wounded sounds exaggerated and unreal. In Hedayat's story, Dash Akol, mortally wounded, is carried home; since, naturally, he has little power to continue his battle. One can excuse Kimiai's thoughtless narrating only through the commercial need of that time for action and western movies and culture; however, this imitation created a complicated picture of luti and cowboys. Likewise, Mofied later called Kimiai's characters "phony lutis" - lutis without all the seven traditional articles and not conforming to traditional luti ideology and psychology. This was because 'it was not clear what we were; we were a bunch of cowboys with knives instead of guns" (Naficy, p. 284). By this decision, he reduces Hedayat's otherwise tragic classic movie to an action movie, only to meet the needs of mass media and pander to the whims of the audience.

\section{Character's Thoughts and Feeling}

Regarding characters' thoughts and feelings, Hedayat is more successful. Although in representing characters' feelings, Kimiai takes advantages of music and visual codes; he cannot go beyond some simple scenes by way of plot, throwing some insight into corrupt social morality into the mix, perhaps irrelevantly. Obviously, he fails to meet the depth of Dash Akol's character and emotion. For instance, when he wants to show Dash Akol being enchanted by Marjan's love, we see Dash Akol sitting and brooding while some chained prisoners walk before his eyes, which is more of a cliché than the faithful portrayal of Dash Akol's deep and searing pain. The other example is Dash Akol picking up Marjan's black tissue left behind on the day of the funeral; this might have been intended to symbolize the pain-ridden love involved, but in Hedayat's story, Marjan doesn't possess such an item. This is a rather blunt and direct allusion to Shakespeare's Othello brought quickly to the audience's attention; however, this symbolic use of tissue as an emblem of love has little place, if at all, in Iranian culture, and therefore, little if any trigger in the audience's minds (Fiad, 2003). As Thomas Leitch (2010) pinpoints in his article, in a successful adaptation, the director should not only study the source text, but also the context surrounding that story should be brought alive in the film. Kimiai's other mistake is the dancer scene. This scene is an abrupt, naïve ending (Fiad, 2003). To represent Dash Akol's agony and suffering, the scene paints him as being satisfied by a few words articulated by a dancer, a brief scanty scene in which the dancer merely sits near him, looks at his face. Fiad (2003) regards the dancer scene as a defect in Kimiai's work, for cinema provides better 
techniques to show characters' thoughts rather than reducing Dash Akol's deep, genuine, and noble feeling to a mere melodrama.

An effective way to represent a character's train of thought is to show a shot of the character's eyes followed by a shot of the object that has caught her or his attention (shot glance followed by shot object) (Herman et al, 2005, p. 601). Kimiai takes advantages of this technique effectively; while Marjan's mom informs Dash Akol of Marjan's imminent marriage, the POV shot moves from his sad, tearful eyes to a miniature picture of a beautiful woman on the wall, and then moves to the other room, in which Marjan is eavesdropping with equally tearful eyes. Thus, the subjective camera invites the viewer to catch Dash Akol's train of thought and feel his deep disappointment.

Kimiai spares Marjan a few chances and scenes of subjectivity and point of view through this technique. One example is when Marjan sets Dash Akol's prayer mat and watches him from the next room, the scene vividly picturing her subjectivity with him, especially where Dash Akol is aware that Marjan has set the prayer mat for him. As Naficy points out, "the scene of Marjan's point of view thus conjoins the subjectivity of Dash Akol with Marjan, creating a powerfully erotic charge between them, which ironically happens in a religious ritual." (Naficy, p. 291). Yet her point of view suggests that she is an observer rather than an active agent of her fate, for "in another powerful scene, Marjan watches from behind the curtain of her room the activities of the servant in the yard preparing for her wedding, emphasizing that she is only the observer of her own fate, not an agent in its transformation" (Naficy, p. 291).

\section{Character Existence}

Characters in stories are presented verbally, with readers having to construct them in their mind according to the textual clues. But in movies, viewers confront real people; for instance, in Kimiai's movie, the viewers see Behrooz Vossoughi, Jaleh, Shahrzad, Bahman Mofid and Mery Apik and other actors starring with their photogenic, body movement, acting style, accent and their particular gestures bestowing depth on verbal characters created by Hedayat. The character that we have recreated from Hedayat's story such as Dash Akol may be different from the one we encounter in Kimiai's movie. Kimiai chose Behrooz Vossoughi for the role of Dash Akol, who is a quite handsome actor, while as it goes in the story, Hedayat's Dash Akol is not very handsome. "Dash Akol was a thirty-five-year-old man, robust but rather ugly. Seeing him for the first time, most people would be repulsed.[...]" (Hedayat, 1995, para.19).

Hassan Fiad (2003) believes that among Kimiai's cast, Bahman Mofid, playing Kaka Rostam, is closer to Hedayat's story, but other members of the cast such as Jaleh and Mery are not successful. Behrooz Vossoughi is not compatible with Hedayat's Dash Akol, for Behrooz Vossoughi is a decidedly handsome actor of Iranian cinema, while Hedayat's Dash Akol is depicted as being not very handsome. Kaka Rostam also deviates from Hedayat's story, for "Kaka Rostam has a stutter and this is a known and accepted fact in the story, yet in the movie he does not stutter" (Rewalk, 2008). This fact casts him in a different light. The major difference was the new character of the dancer (Rewalk, 2008). In the movie, Dash Akol has the chance to meet Marjan at the funeral ceremony and some other scenes, but in the story he does not. "The movie concentrated mostly on the feud between Kaka Rostam and Dash Akol rather than Dash Akol's love for Marjan as in the story" which approximates the movie to an action tough-guy one rather than a tragic love story (Rewalk, 2008).

Hedayat's story is a short story and obviously does not have enough spans to characterize all characters. For instance, readers learn about Marjan through Dash Akol's imagination and eyes. Except two scenes, one at the beginning and the other at the end, she is absent from the main stream of story, reminding the reader that the story is happening in a traditional context; the reader never hears a single word from her. She is silent, and one hardly learns about her feeling and keeps wondering whether she loves Dash Akol back at all. At this point, one should also refer to a crucial issue of character existence; not all characters exist in the story world. In Uri Margolin's (2007) words, characters may not exist in the textual-actual world, but merely in the belief, wish, intention, or imagination sphere of other characters. Thus a character is not only in part the construct of the writer and the narrator, but also the outcome of another fictional character's mind (Herman et al, 2005). In this respect, one can say that Marjan is the outcome of Dash Akol's mind rather than the narrator, and this may just be what invests the story with such lasting allure and literary appeal.

However, in Kimiai's movie, Marjan has a more active role; for instance, she is curious to know and learn more about Dash Akol, something decidedly at odds with the tenor of the short story. As it was discussed, Kimiai gives Marjan some chances of subjectivity. She asks her mom about Dash Akol's 
character, yet, except a few seconds in the funeral scene; she never meets him in person.

In terms of gender representation, in Kimiai's movie, women are bestowed with a more vivid subjectivity. Down the line, Kimiai's creation of Aqdas, which could also be regarded as a foil character for Marian, is a creation of an agent for voicing Iran's culture of the 1970s and satisfying the audience's desire for a full and graphical picture of a sexual relation. The Iranian cinema in the 1970s experienced an explosion of sexual incitement. Box-office success of movies of that time depended for their success on picturing and fulfilling cardinal desires; Middle-class audience derived pleasure from voyeuristically watching the scenes of male female relations.

Kimiai's aberration is in fact his response to the diasporic atmosphere of Iran which demanded a hybrid creature of western and Iranian type. Aqdas is Marjan's modern and westernized alter ego, one who escapes from the confined private space of home to the public sphere, losing Marjan's dignity and purity but being bestowed with the expression of love and freedom of sexuality. However, in a masculine misogynist context, she is still relegated to a trifling place and not a real object of love. Dash Akol's expression of platonic love is for the respected, dignified Marjan and his cardinal physical love for impure, degraded Aqdas.

\section{Direct and Indirect Characterization}

Characters could be presented directly or indirectly. To define a character directly, the narrator utilizes explicit characterization techniques. This style of characterization consists of descriptive statements that identify, categorize, individualize and evaluate a person (John, 2003). In this type of characterization, the traits are named by an adjective, and abstract noun, or part of speech, for example: "he loves only himself' (Rimmon-kenan, 2002, p. 59-60). Hedayat uses this technique artistically. He puts Dash Akol and Kaka Rostam' characteristic descriptions against one another and brings about the formation of the hero and antihero simultaneously; in fact, the encounter of Dash Akol and Kak Rostam not only does describe, but also categorizes and individualizes their traits:

Everyone in Shiraz loved Dash Akol... In fact, he was kind to people; if anyone dared harass a woman, or tried to bully people, Dash Akol made him pay for it through the nose. He could be counted on to help people in financial distress and sometimes even to carry their heavy parcels.
In indirect characterization, the traits are not mentioned but displayed and exemplified in various ways, leaving to the reader the task of inferring the quality they imply (Rimmon -Kenan, 2002, p. 60). There are a number of ways to display characters indirectly, such as action, speech, external appearance, setting and naming.

\section{Action}

In terms of action, a trait may be implied both by "one time action" and "habitual" ones (Rimmon-Kennan, 2002). In the story and the movie, we learn about Dash Akol's integrity and nobility while he fights back his painful love for Marjan because "he felt that if he married the girl who had been his charge, it would be a betrayal of Haji's trust", (Hedayat, 1995, para.23) and from the scenes in which he defeats Kaka Rostam but doesn't kill him. The other scenes are when Dash Akol appears out of the blue to rescue a woman and her child from Kaka Rostam's hands. Also in the last scene, he puts his cutlass as ideas. Kaka Rostam's cutlass fell over and fights him bare handed, but Kaka Rostam picks up the same cutlass and stabs him from the side; in these scenes, we learn about Kaka Rostam's wickedness as well.

In terms of their habitual behavior, they both claim to be the lutis of the city (luti connotes two opposite codes of behavior: one a loose-living and wineimbibing or a lout, the other one javanmardi and manliness traits), but their habitual characteristics make one a luti and the other a lout. Kaka Rostam smokes opium and makes a living by causing trouble, intimidating and extorting money from people, while Dash Akol is the one who helps the poor and is famous for traits of manliness. As Hamid Nafisi points out in his study the social history of Iranian cinema:

In Dash Akol, the plot revolves around the personal rivalry between the luti type whose era is fading (Dash Akol) and the lout type who is in ascendance (Kaka Rostam). Kaka Rostam chases Dash Akol's status as the neighborhood's chief luti. Were Kaka Rostam to have survived, however, his antisocial and villainous conduct would have prevented his transformation from a lout to a luti. (Nafisi, 2011, p.276).

\section{Speech}

Character's speech, as Rimmon-Kenan (2002) suggests, a character's speech, whether in conversation or as silent activity of the mind, can be indicative of both a trait and traits through form (p.63). Thus, when Dash Akol and Kaka Rostam talk, they not only convey the information they have in their minds, but 
also simultaneously reveal their own character traits. For instance, when Dash Akol is promising Haji's wife that he will carry out Haji's will, he reveals his Javanmardi and manliness traits.

\section{Setting}

Setting is the environment in which story-internal characters live and move about (Herman et al, 2005, p.552). Rimmon-Kenan (2002) defines environment as a character's physical surroundings (room, house, street, town) as well as his human environment (family, social class), also often used as traitconnecting metonymies (p. 66). The story takes place in a traditional, religious atmosphere of an old, Iranian city, Shiraz. The fact highlights and confirms Dash Akol's traditional character and his ideological beliefs. Dash Akol and Kaka Rostam both are from one town, and a special period of time, but the quality that makes them different is their family and class.

It seems what transforms Dash Akol from a lout into a luti is his rich background. He is from an aristocrat family, and the son of a notable landowner. He is the one who is expected to follow javanmardi traits and resists the love for Marjanonly to keep with manly codes of behavior he has been brought up with Ironically, the same setting and ideology make him fall in love with Marjan, a girl who is quite a child rather than a grown-up girl capable of love. For as Kimiai portrays her on the funeral day, Marjan, a teenager, is dressed along the lines of her mom and other mature women; she is wearing a chador and a veil which is quite odd to the contemporary Iranian's mind. Thus, Hedayat chooses old Iranian setting and culture in which the possibility of marriage with a girl much younger than the man exists, as seen later in the story, where Marjan's suitor is even older than Dash Akol.

\section{Naming}

When it comes to naming, according to Ewen (1998) (cited in Rimmon-Kenan, 2002, p. 68), there can exist semantic connections between names and character traits. Names in Hedayat's story convey a good deal of information about characters' role and reveal their traits; for instance, Dash implies the meaning and connotation of brother, generous, nobleman. On the other hand, Kaka Rostam is the combination of two contradictory names; Kaka implies the meaning of a baby and a child, while Rostam is the name of a Persian hero. This name instantly achieves a contradiction; he could be a hero but he fails to be one. The same goes with the name Marjan which is originally the name of types of coral that assume quite beautiful colors under the sea. This is compatible with Dash Akol's beautiful beloved, but corals can also remind hardship, unavailability and peril. One can only conceive of dipping under the sea and dislodge a coral stone or reef using painstaking means or braving many dangers of the sea. Mullah Esaac's name, the one who serves Vodka (aragh), is quite telling; Esaac, a Jewish name, implies that he is a Jew and not a Muslim; hence he is likely to serve alcoholic drinks, since in the Islamic religion, serving and drinking alcohol are taboo. But Mullah is the name originally denoting an Islamic cleric that later came to be attached to other proper nouns as a prefix denoting traits at least remotely similar to a Mullah. This is still a practice upheld in Pakistan and Afghanistan but not in Iran anymore, at least not in the blatant violation of what the name suggests and what Mullah Esaac does in the story, a purveyor of spirits! These examples point to Hedayat's success in taking advantage of naming techniques informing his characters.

\section{Focalization}

Some narratingmethods were discussed above. These issues concerned the question of "who speaks?". Now it is time to pose the question "who sees? Genette (1988) draws a distinction between focalization and narration by putting forward the question 'who sees?' as opposed to 'who speaks?' (p.186). The story is presented in the text through the mediation of some angle of visions, verbalized by the narrator though not necessarily by characters (Rimmon-Kenan, 2002, p. 72). By choosing the focalizer or focalizers in the story, the narrator manages the channels for characterization. In fact, what a focalizer sees or perceives is directly or indirectly connected to his or her character and background. Hedayat uses this technique ingeniously. He gives a very good picture of Kaka Rostam while giving the reader the chance to see Kaka Rostam through Dash Akol's eyes or lens of vision. Hedayat uses Dash Akol as the Focalizer. Through this method, not only does he describe Kaka Rostam's character, but reveals Dash Akol's as well. The reader learns that Kaka Rostam is a person who causes people ample and ceaseless trouble, who drinks, smokes opium, and, meanwhile, is afraid of Dash Akol. By telling these words, Dash Akol simultaneously reveals his own character; the reader learns that he is the people's person, a supporter, a strong man sensitive to people's hardship and rushing to their help, a 'luti'. When he swears to Pouria-ye Vali, we learn about his belief, that he is the one who could defeat Kaka Rostam, using bitter, witty, and sarcastic language all at once. Here are some lines whereby the reader can see Kaka Rostam from Akol's angle of vision: 
Suddenly, out of nowhere, Dash Akol had arrived to ridicule him, "Kaka? Where's the man of the house? Did you smoke an overdose of opium? Man, it has affected you! But let me tell you my friend, put these cowardly, dastardly pranks aside. You're behaving like a lout and you are not even ashamed of it! Is this a new method of begging? Why do you abuse people by stopping them on their way home night in and night out? Try it again and, by Pourya the Valiant, I shall teach you a lesson. I'll slice you in half with this cutlass." Kaka Rostam had put his tail between his legs and had left (Hedayat, 1995).

Narrators usually utilize "characters as center of consciousness" or "reflectors" that help the reader or spectator see the story world through their eyes (Stam et al, 2005, p.88). Other examples are when Hedayat reasons why Dash Akol can't have Marjan as wife. He presents Dash Akol' reflections, through which we see him as he sees himself:

Every night he surveyed himself in the mirror... Sadly he would say to himself, "Marjan would never love me. Most likely, she'll find a handsome, virile young man for a husband ... No. This is far from chivalry. She's a mere child of fourteen while I'm forty-years old. What's to be done? This love will be the death of me. Marjan, you're killing me. In whom can I confide? Marjan, your love is killing me." (Hedayat, 2005)

However, in the movies we have ocularization, a term Francois Jost (1984) used in his article "Narration(s): On this Side of and Beyond". He mentions that there exists a problem in identifying a cinematic narrator, because we are not always able to say who is doing the telling using a series of images (cited in Stamet al, 2005, p 91-92). It is because "the sound film can simultaneously show what a character sees and say what a character thinks" (Stam \& Raengo, 2005, p. 40). In order to avoid this confusion, Jost introduces the concept of "ocularization." Focalization refers to that which a character knows; ocularization indicates the relation between what the camera shows and what a character sees. Internal ocularization would refer to those shots where a camera appears to take the place of the character's eye. External occularization (or zero ocularization) would indicate those shots where the field of vision is located outside the character's own (Stam et al, 2005, p. 93).

The outstanding scenes in Kimiai's movie, where the subjective camera takes the place of a character, are when it sees through Dash Akol's eyes, especially the scene where he looks at a miniature picture of a woman on the wall, Marjan's black tissue or the dancer. As for interior occularization, two outstanding and memorable examples are when the POV shot sees through DashAkol's eyes and catches Marjan's eyes for the first time on Haji's funeral day, and the other one when he catches Marjan's eyes for the last time on her wedding day beyond the window while his eyes are full of tears.

\section{CONCLUSION}

This research was an interdisciplinary study of the source text and the movie Dash Akol. It compared the underlying narrative structure of Hedayat's original short story and Kimiai's movie based on it. The paper also provided explanations and reasons for the discrepancies between the short story and the movie, and pointed to the factors which made the tragic love story into the tough-guy action movie. To conduct a comparative study of these two works, it drew on Genette's narrative strategy and Rimmon-Kenan's characterization techniques. Meanwhile, it evaluated the perceptibility and reliability of narrative in Hedayat's story and in Kimiai's movie through analyzing discrepancies between the Iranian cultural context of the 1920s and those of the 1970s. It propounded that the movie adds and changes some scenes due to the need of the time for representation of the silent and repressed aspects of the story, reinterpreting it into a hybrid modern tough-guy movie. The characters' speech, thoughts and feelings were also discussed. Direct and indirect characterizations were another dimension in this study as two modes of narrating. We also looked into indirect characterization through four characteristic attributes, namely, speech, action, setting and naming. Gannett's focalization was the last part of this paper.

Dash Akol's story is one that takes place in a deeply traditional and religious atmosphere of old Iran, where religion, tradition and feeling are interwoven in a masterful and succinct portrayal of human emotion, pain and challenge. It could serve as a rich source engaging with which would contribute to follow-up studies and the decoding of ideological facts regarding men, women, and the luti/javanmardi culture as well as the image of strong, reliable, pure-hearted men acting as valiant helpers of the destitute and the oppressed.

\section{REFERENCES}

Chatman, S. (1980). Narrative discourse. The Journal of Aesthetic an Art Criticism. 39(2), 221-24. 
Fiad, Hassan. (2003). Dash akol: Melodrami az yek tragedy dardnak, Dafter e Honar. (p. 1382). From http:// www.researchDash AkoMMy Disc Wash Akol.mht

Genette, G. (1988). Narrative discourse: An essay in method. New York: Cornell University Press.

Hedayat, S. (1995). Dash Akol. In I Bashiri, (Ed) \& K. Brown (Trans.). Availabe from http://www. angelfire.com/rnb/bashiri/Stories/Dashakol,html. Hedayat.

Kimiai, M. (1971). Dash Akol [Film]. Studio: Pars Film, Tehran.

Hedayet, S. (1998). Se ghatrehkhoon. Tehran: Javidan publishing.Tehran.

Herman, D., Jahn, M. \& Marie-Laure. eds. (2005). Routledge encyclopedia of narrative theory. Oxford Shire.

Leitch, T. (2010). Adaptation studies at a crossroads. Oxford Journals. 2 September.

http://www.Adaptattion Studies at a CrossroadsAdaptation.

Margolin, U. (2007) The Cambridge companion to the narrative: Character, (D, Herman,ed.).
Cambridge University press. DOI:http://dx. doi.org/10.1017/CCOL0521856965.005

Nafisi, H. A social history of Iranian cinema, volume 2: The industrializing years. 1941-1978. Duk University Press. 191.

Prince, G. (2003). A dictionary of narratology. $2^{\text {nd }} \mathrm{ed}$. Lincoln and London: University of Nebraska Press.

Rewalk, Dash Akol Analysis. Study Mode.com. Retrieved 11, 2008, from http://www.studymode.com/essays/Dash-Akol-Analysis-184218. $\mathrm{html}$

Rimmon-Kenan, S. (2002). Narrative fiction. London: Routledge.

Sanders, J. (2006) Adaptation and appropriation. London: Routledge.

Stam, R. \& Raengo, A. (2005). Literature and film. Great Britain: Blackwell Publishing.

Stam, R., \& Robert, B., \& Flitterman-Lewis, S. (2005) New vocabularies in film semiotics, Taylor \& Francis e-library.

Welsh, J. M., \& Peter Lev, eds. (2007). The literature/ film reader: Issues of adaptation. Lanham, MD: Scarecrow. 